\section{Veinticinco años de arquitectura religiosa}

\section{Twenty five years of religious architecture}

IGNACIO VICENS HUALDE

https://doi.org/10.17979/aarc.2007.1.0.5018

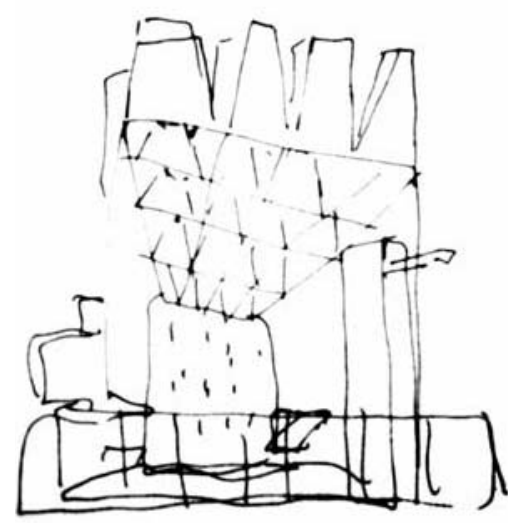

Iglesia parroquial de la Santísima Trinidad, Collado Villalba (Madrid), 1996/99. Croquis.

\section{FUNDAMENTOS TEÓRICOS}

Después de las dos intervenciones de esta mañana, se impone que haga algún tipo de reflexión, y lógicamente las palabras que voy a decir ahora, en mi propia intervención, de alguna manera iniciarán la polémica que espero que continúe después, en la mesa redonda. Pero no podía ser menos, dado que algunas de las afirmaciones que se han hecho chocan claramente con mi concepción de lo que es la arquitectura sacra. Eso es lo bueno de un congreso: que se exponen todo tipo de opiniones y se trabaja para llegar a consensos y para enriquecer, pues, las propias apreciaciones personales.

\section{En busca de la objetividad}

Desde luego, lo primero que tendría que decir es que estoy muy de acuerdo con Esteban Fernández Cobián en que es imprescindible erradicar, en todo discurso sobre el arte sacro, cualquier tipo de referencia a los sentimentalismos vaporosos, a las experiencias religiosas o a los espacios místicos: creo que es, sencillamente, imprescindible. Lo nuestro tiene que ser $-\mathrm{y}$ más en un congreso de este tipo - un trabajo lo más objetivo posible, con referencia a las fuentes y no mirándonos el propio ombligo intelectual: yo pienso, yo quiero, me parece... Cuanto más objetivas sean nuestras aproximaciones, más generalizables - y por lo tanto, más interesantes - serán. Esto creo que es extraordinariamente importante, y por ello no voy a hacer nunca referencia, insisto, a esos sentimentalismos más o menos vaporosos y etéreos que tienen relación con el gusto, con las experiencias místicas, con aquello que excita la piedad, etc. Mi discurso intentará estar radicalmente alejado de todo ello.

Creo que todo lo que se refiere a la arquitectura - la arquitectura es una cosa muy seria: muchos de nosotros le hemos dedicado nuestra

\section{Theoretical background}

After the two presentations from this morning, I should make some sort of reflection and, obviously, the words I intend to utter during my speech will somehow kick off the controversy that I hope will be continued later during the roundtable discussion. But it could not be otherwise, given that some of the statements made clearly clash with my approach to sacred architecture. That is the good thing about a conference, that all sorts of opinions are expressed and that people try to reach a consensus and to widen their own personal horizons.

\section{In Search of Objectivity}

Certainly, the first thing I should say is that I very much agree with Esteban Fernández Cobian when he says that it is necessary to eradicate, in every discussion about sacred art, any type of reference to fuzzy sentimentality, to religious experiences and to mystical spaces: I think that it is absolutely indispensable. Our work should be as objective as possible- particularly at this kind of conference-referring to the sources instead of looking in our own intellectual mirror: I think, I want, I guess... The more objective our approaches, the more general and interesting they are. I believe that this is extraordinarily important, and, therefore, I will never refer to those more or less fuzzy and ethereal sentimentalities which are related to taste, to mystical experiences, to that which moves towards devotion, etc. My speech will try to remain radically detached from all that. 
I believe that everything related to architecture is a very serious stuff. Architecture is very serious: many of us have devoted our lives to it because we think that it is interesting enough to devote your life to it. It is something very serious requiring research, preparation and work and which cannot be summed up with I feel like, I like, I am interested in, etc. We must carry out well-thought analyses, intellectual efforts, laborious reflections about the purpose of our study, in this case, just to advance the topic, liturgical provisions. I certainly agree with the title of the first round-table discussion: the liturgy is the programme. We should make it clear as soon as possible that, in this regard, for an architect faced with the topic of sacred art, the liturgy is the programme. Because if we do not do it that way, we will be filling up churches with mediocrity - and I repeat it- because I have by me a quote by Cardinal Daneels talking about it. If certainly many of the recently built temples and churches are mediocre, that is because they lack soul, because they are trivial, because there is no intellectual structure behind them. One of the characteristics of mediocre architecture is always its lack of theory.

I am fully convinced that goodwill lacking theoretical muscle can only produce banalities, useless areas. Unfortunately, I think that many of us are used to see many areas lacking liturgical sense in the field of sacred architecture. They are wilful approaches, done with goodwill but devoid of depth. Those spaces show that there has been no reflection about the liturgical provisions.

Liturgical provisions are the starting point

Well, since none of us present believe that temples can be materialised in terms of nonsignificant shapes, in terms of irrelevant shapes, I think that from now on we should reach the conclusion that researching the liturgy - a deep research of the liturgy - is unavoidable. This is where I must express my disagreement with something that was said in the morning-although, I insist - these are just some brushstrokes of what will come next. When I say researching the liturgy, I say what I say. It is clear that, for an architect like me, who is intent on developing sacred architecture, just like many of you, the acceptance of the liturgy as it comes is our starting point. Following some of the things said here this morning, please let me recall a short paragraph from John Paul II's speech on the celebration of the 20th anniversary of the "Sacrosanctum Concilium», in 1984: the former Pope said in 1984 that there was and still is some reluctance by certain individuals or groups who have viewed the liturgical reform with distrust from the beginning. This is a vida porque consideramos que es algo suficientemente interesante como para dedicarle la vida - es algo muy serio que exige estudio, que exige preparación y trabajo y que no puede despacharse con un me apetece, me gusta, me interesa, etc. Tenemos que hacer análisis meditados, esfuerzos intelectuales, reflexiones trabajosas sobre lo que será el objeto de nuestro estudio, que son - lo adelantó ya al principio - las disposiciones litúrgicas. Porque estoy muy de acuerdo con el título de la primera mesa redonda: la liturgia es el programa. Dejemos claro cuanto antes que, en este sentido, para un arquitecto que se enfrenta con el tema del arte sacro, la liturgia es el programa. Porque si no lo hacemos así estaremos llenando una vez más - y digo una vez más, porque tengo aquí una cita del cardenal Daneels en donde habla de esto- las iglesias de mediocridad. Y si realmente muchos de los templos y de las iglesias que se han realizado últimamente son mediocres, es porque les falta alma, porque son banales, porque no tienen ninguna estructura intelectual detrás. Porque una característica de toda arquitectura mediocre es, siempre, su déficit de teoría.

Estoy plenamente convencido de que la buena voluntad carente de musculatura teórica no produce más que banalidades, ámbitos que no sirven para nada. Y, desgraciadamente, creo que todos nosotros estamos acostumbrados a ver en el tema de la arquitectura sacra muchos ámbitos que están desprovistos de sentido litúrgico; aproximaciones más o menos voluntaristas, con muy buena voluntad, pero que están exentas de profundidad. Y porque no tienen esa musculatura teórica, al final se convierten en banales. Son espacios en los que se nota que no ha habido una reflexión sobre las disposiciones litúrgicas.

\section{Las disposiciones litúrgicas son el punto de partida}

Bien. Como ninguno de los que estamos aquí presentes creemos que los templos pueden formalizarse en términos de formas no significantes, de formas irrelevantes, creo que es importante que ya desde ahora lleguemos a la conclusión de que el estudio de la liturgia — el estudio profundo de la liturgia - es imprescindible. Y aquí tengo que proponer la primera de mis discrepancias con lo que - aunque insisto, estos van a ser una serie de bocetos de lo que vendrá después - aquí se ha dicho esta mañana.

Cuando digo estudio de la liturgia, digo lo que digo. Queda claro que, para un arquitecto como yo - empeñado como muchos de ustedes en la ardua tarea de sacar adelante arquitectura sacra - la aceptación de la liturgia tal como viene dada es un punto de partida. Al hilo de alguna de las cosas que he ido oyendo esta mañana, me permitirán que recuerde un pequeño párrafo de la alocución que Juan Pablo II hizo conmemorando el vigésimo aniversario de la «Sacrosanctum Concilium», por lo tanto en 1984: «Ha existido — decía el Papa en 1984, el anterior Papa-, ha existido y existe todavía resistencia por parte de individuos o grupos que, desde el comienzo, han acogido con desconfianza la reforma litúrgica». Esto es una queja que a mí realmente me afecta. Que el Papa se queje que después de veinte años todavía haya gente que siga acogiendo con desconfianza — dice él— la 
reforma litúrgica, creo que es grave. Dice después - y esto es lo que creo que nos puede servir a nosotros, o al menos yo quisiera que fuera la pauta de conducta para mí: la fidelidad a la liturgia - que se basa en la profunda convicción de que la liturgia es establecida por la Iglesia, y que los fieles no son sus propietarios, sino sus servidores. Y termina con una frase bellísima: «Tal fidelidad contempla también la apertura y la disponibilidad a aquellas adaptaciones que la misma Iglesia permite y alienta».

Creo que es importante que nosotros, arquitectos comprometidos con el arte sacro, tengamos esta actitud de fidelidad, sabiendo que la liturgia es un dato, es un programa que nos viene dado, que no somos sus propietarios y que no podemos tampoco interpretarla. Y que en estos cuarenta y tantos años, no sólo se ha promulgado la «Sacrosanctum Concilium», sino todas las disposiciones posteriores que han ido desarrollando un cuerpo doctrinal fascinante, que tenemos que amar. Insisto: amar.

No criticar ese amor será, evidentemente, como todo amor, activo. Y todos nosotros, siguiendo también las enseñanzas y la petición de la misma «Sacrosanctum Concilium», nos empeñaremos en hacer cada vez más vivo, más eficaz, el diseño de esos nuevos ámbitos, que se nos pide a los arquitectos que resuelvan perfectamente las nuevas disposiciones litúrgicas.

Seguiremos luego, porque mi intervención yo la he planteado también en términos arquitectónicos, como un arquitecto que tiene práctica profesional en esto. Pero creo que es importante subrayar que la crítica a esas disposiciones litúrgicas no me parece adecuada para nosotros, los arquitectos.

\subsection{La arquitectura sacra debe tender a la excelencia}

Quiero, antes de seguir, decir una segunda cosa que creo que es importante. Característica necesaria de la arquitectura sacra debe ser la excelencia, o al menos, la tensión hacia ella. Y esto creo que es especialmente interesante decirlo ahora, porque mi propia experiencia $-\mathrm{y}$ supongo que la de muchos de ustedes - está impregnada de un cierto desánimo, que viene de ver cuántas veces la arquitectura sacra se afronta en términos «realistas», que no hacen más que enmascarar perezas objetivas. Se dice que no hay dinero, que no hay presupuesto. No: sobre todo, no hay interés. En un momento en el que el hombre ha llegado a la luna, seguir hablando de que no existe dinero para todo esto quiere decir que no existe interés, que no existen ganas de trabajar, que no existen ganas de complicarse la vida y que se busca una especie de «áurea mediocritas» que a nadie disguste y que supone una vulgaridad inaceptable.

Esta es mi experiencia. A lo mejor es un poco crítica. Yo no soy pesimista — que quede claro-, si no, no estaría aquí, me hubiera dedicado a otro tipo de cosas. Pero no ser pesimista no quiere decir no afrontar la realidad tal como es.

Me temo que en las circunstancias actuales, el arte sacro y concretamente la arquitectura religiosa, luchan contra un terrible enemigo interno, que es la falta de interés, la voluntad de no buscar la excelencia sino de pasar inadvertido, con recintos que resuelvan problemas de alojamiento para los fieles, complaint which affects me personally. The fact that the Pope complains that, after 20 years, there are some people who still feel reluctant about the liturgical reform is something serious. He says later on -and this can be useful for us, or at least I would like to turn it into a personal guideline: the faithfulness to the liturgy - is based on a deep conviction that the liturgy is established by the Church and that the faithful are not its owners, but its servants. He ends with a beautiful sentence: "that faithfulness also contemplates the openness and availability for those adaptations allowed and promoted by the Church».

I believe that it is important for us, architects who are committed to sacred art, to keep this attitude of faithfulness, knowing that the liturgy is a detail and a given programme, that we are not its owners and we may not interpret it. In more than 40 years, not just the «Sacrosanctum Concilium» has been promulgated, but all the previous provisions integrating a fascinating doctrinal corpus that we should love. I repeat: love.

Not criticising that love will mean, obviously, an active love. All of us must try to make the design of those new zones, following the teachings and requests of the same "Sacrosanctum Concilium», more and more lively and efficient, since architects are asked to solve the new liturgical mandates perfectly well.

My presentation has been approached in architectural terms, from the viewpoint of an architect who has a professional career in the field. However, I think that it is worth mentioning that architects are not in a position to criticise those liturgical provisions.

Sacred architecture should aim at excellence

Before continuing, I would like to mention a second important idea: excellence must be a necessary characteristic of sacred architecture or, at least, the tension towards it. I believe that it is particularly relevant to say this now, because my own experience - just like the experiences of many of you-is impregnated with a certain disenchantment coming from the fact that sacred architecture is often approached in realistic terms which just mask certain objective laziness. They say that there is no money, no budget. No: above all, they lack interest. At a time when human beings have reached the moon, saying that there is no money available for all this means that there is a lack of interest, there is no desire to work, people do not feel like complicating their lives and look for some sort of aurea mediocritas which does not bother anyone and stands for an unbearable mediocrity. 
This is my experience. It may be a little too critical. I am not a pessimist -I should make it clear-; otherwise, I would not be here, I would have been doing different things. Although not being a pessimist does not mean not facing reality as it is. I fear that, in the current circumstances, sacred art and, in particular, religious architecture, are fighting against a horrible internal foe: a lack of interest, the desire not to search for excellence but to remain unnoticed, with facilities solving the believers' accommodation needs, where there is no rain, where, I do not know, anything which is not excellent. Because excellence is always troublesome, and it should not be so. Really, if excellence is appropriate somewhere that is in sacred art.

The «Sacrosanctum Concilium» already asked architects for an extraordinary effort and not just architects, but every true artist. I quote by heart, though with more or less literal words: contemporary art should also unite its voice to the admirable concert put together for Jesus Christ by the previous centuries ${ }^{1}$. That union cannot be achieved without excellence.

The main value of a work of sacred art is determined by its job as work of art. The same could be also true of the main value of religious architecture which is determined by its architectural value. And that is so. Talking about the dignity of the architectural work and of the work of sacred art is unavoidable nowadays when people are usually uninterested.

If there is enough time left -I would not like to exceed my time, I guess that I have one hour-I intend to review the icons put forward by the 20th century to history, in terms of sacred art. I fully understand the criticism made by Cardinal Daneels: usually, a barbarism.

Well, before proceeding, I would like to make clear that, obviously, I have made a clear reflection; I have thoroughly researched Andrés Pardo's Enchiridion ${ }^{2}$. We will examine later on a few topics related to the liturgy. The liturgy is the programme, it has been well written here and I fully agree. The liturgy is the programme, though liturgical requirements are not always well understood. Out of the set of works which I will present here, I believe that there is only one that did not fail. Why? I have mentioned that the recently finished century has produced, in particular in its second half and specifically in Spain, banal religious architectural structures. I believe that blaming it all on architects would not be fair. It is better not to blame anyone, but I believe that it is not fair. A reflection about the Spain from the 50s to the 60s: it was a ruined and miserable Spain which had just emerged from a horrendous war, which had no kind of outer aid, which had to rebuild itself and which, objectively, had no resources donde no llueva, donde no sé qué, pero que no tengan excelencia. Porque la excelencia es siempre problemática. Y esto no puede ser. De verdad: si en algún sitio la excelencia es obligada, es en el arte sacro.

Ya la «Sacrosanctum Concilium» nos pide un esfuerzo extraordinario a los arquitectos $\mathrm{y}$, en general, a todos los artistas de verdad, para que — cito de memoria, pero con palabras más o menos textuales — también el arte de nuestro tiempo una su voz al admirable concierto que los siglos precedentes erigieron en honor de Cristo ${ }^{1}$. Y esa unión no se puede alcanzar sin la excelencia.

El valor primero de la obra de arte sacro viene determinado por su labor como obra de arte. Y podríamos decir lo mismo del valor primero de la arquitectura religiosa, que viene determinado por su valor arquitectónico. Y esto es así. Hablar de la dignidad de la obra arquitectónica y de la obra de arte sacro creo que es imprescindible hoy en día, cuando habitualmente no interesa.

Si hay tiempo luego - no quiero pasarme, tengo una hora, me parece-, me gustaría que hiciéramos un pequeño repaso para ver cuáles son los iconos que el siglo XX, en términos de arte sacro, propone a la historia (uno comprende perfectamente las críticas del cardenal Daneels): una barbaridad, casi siempre.

Bien, antes de seguir quiero también dejar claro que, como es lógico, he reflexionado claramente; el Enchiridion de Andrés Pardo lo tengo muy trabajado $^{2}$. Veremos luego algunas cosas sobre el tema de la liturgia. La liturgia es el programa, lo hemos dejado bien escrito aquí y estoy totalmente de acuerdo. La liturgia es el programa, pero los requerimientos litúrgicos no siempre son bien entendidos.

De mis obras que voy a exponer aquí, sólo una la consideró no fracasada. ¿Y por qué? Cuando antes hablaba de que este siglo que acaba de terminar ha producido, sobre todo en su segunda mitad y en España concretamente, estructuras arquitectónicas religiosas banales, creo que sería injusto echar toda la culpa sobre los arquitectos. Mejor no echar las culpas sobre nadie, pero creo que no es justo.

La reflexión de lo que pasó de los años cincuenta a los sesenta en una España arruinada, miserable, que acababa de salir de una guerra espantosa, que no tenía ningún tipo de ayuda exterior, que tenía que reconstruirse y que, objetivamente, no tenía recursos para nada y que sin embargo supo ofrecer el más admirable ejemplo de arquitectura sacra del siglo XX, en mi opinión - $\mathrm{y}$ creo que comparto la opinión de dos personas que han hecho sus tesis sobre ello, Esteban Fernández Cobián y Eduardo Delgado Orusco, que están aquí delante- nos deja bien claro que cuando faltan los recursos tiene que abundar la creatividad. Los ejemplos de Fisac, de Carvajal, de Oíza, de Fernández del Amo y no sigamos, porque están en la mente de todos ustedes, muchas veces en poblados de colonización o en poblados de absorción, son admirables. Y supieron recurrir a los mejores artistas de la época: aquellos jóvenes Chillida y Oteiza, por ejemplo, empezaron haciendo Vía Crucis para estas iglesias de colonización... Todos 


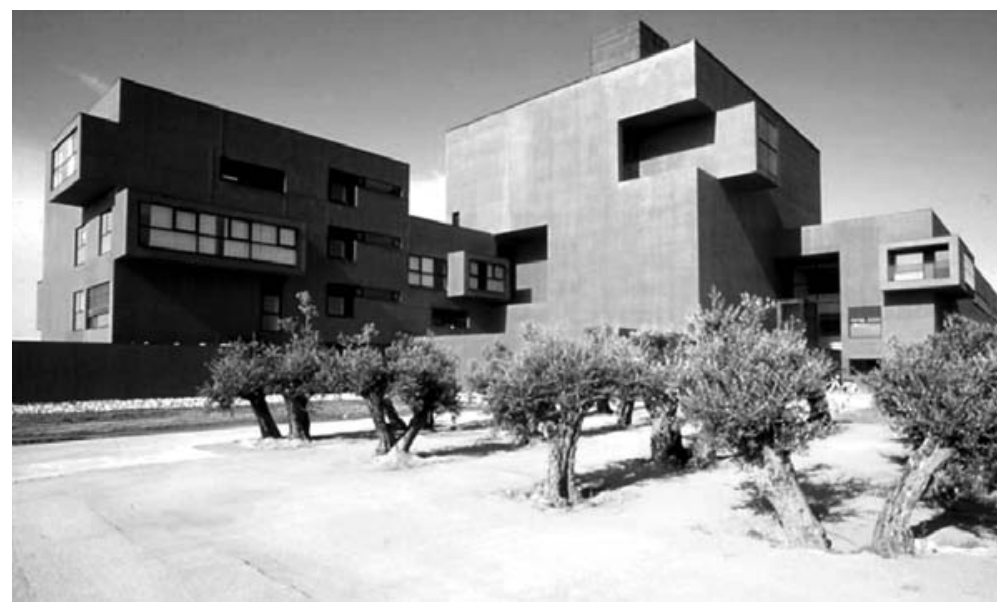

Capilla de la Residencia de las Hermanitas de los Ancianos Desamparados, Alcázar de San Juan (Ciudad Real), 1996.

ellos pudieron hacer esto porque contaban con la confianza de personajes excepcionales. Evidentemente no voy a hacer un elenco aquí: no es el caso, no es el tema; pero cualquier momento es bueno para rendir un pequeño homenaje a personas como ese increíble obispo de Vitoria, que fue capaz de encargar esas iglesias a unos jóvenes insensatos que estaban por allí; como el padre Aguilar, el General de los dominicos o el pobre General de los franciscanos, que recibió todo tipo de presiones hasta del Santo Oficio para paralizar la iglesia de Arantzazu.

\section{Las disposiciones longitudinales no responden a la liturgia}

¿Tenemos estos promotores hoy en día? Creo que, entrando ya en el tema, como arquitecto comprometido tengo que decir que estoy en desacuerdo con la segunda parte de la intervención de Esteban Fernández Cobián; y esto permitirá luego una cierta chispa o polémica en la mesa redonda. Creo clarísimamente que el estudio objetivo de los requerimientos litúrgicos impiden, hoy en día, cualquier tipo -impiden, insisto: luego estoy dispuesto a matizar si fuera necesario - cualquier tipo de disposición longitudinal de las iglesias. Por lo tanto, estoy absolutamente convencido de que los esquemas basilicales, los esquemas de cruz latina, son totalmente inadecuados para la liturgia que nos propone la Iglesia.

Frente a aquella monodireccionalidad en los ámbitos preconciliares en los que todo convergía en un punto privilegiado, en ese presbiterio donde se encontraba el altar - encima del altar estaba también el tabernáculo para la reserva eucarística - en el que se celebraba el sacrificio, detrás estaba el retablo con las imágenes para la veneración de los fieles, todo concentrado en un único punto, una de las cosas que pide la reforma litúrgica — creo que es clarísimo - es separar para clarificar. Nos pide a los arquitectos que separemos: primero, el ámbito de la celebración del available and, nevertheless, it was able to provide the most admirable example of 20th century sacred architecture. In my opinion - which I believe to share with two people who have made their PhD dissertations on it, Esteban Fernández Cobián and Eduardo Delgado Orusco, who are present- it is quite clear that, when resources are scarce, creativity has to be abundant. The examples by Fisac, Carvajal, Oiza, Fernández del Amo, etc., there is no need to continue since they are on our minds, often located in colonisation or absorption settlements, are admirable. They knew they had to resort to the best artists in their time: the young Chillida and Oteiza, for instance, started building ways of the cross for these colonisation churches... All of them could make it because they had the trust of some extraordinary characters. Obviously, this is not the place for a casting: it is not the case or the topic; but it is always a good time to pay tribute to people like the amazing Bishop of Vitoria, who was capable of assigning those churches to some youngsters around there; or Father Aguilar, the Dominican General or the poor Franciscan General who received all types of pressure, even from the Holy Office, in order to stop the church of Arantzazu.

Longitudinal arrangements do not respond to the liturgy

Do we have these promoters nowadays? Beginning now with the subject, and as a committed architect, I must say that I disagree with Esteban Fernández Cobian's second half of the presentation; this will sparkle with a little controversy the round table discussion. I firmly believe that, nowadays, the objective study if liturgical requirements hinder any sort of longitudinal arrangement of churches. I insist: they hinder it, though I am willing to qualify it later on. Therefore, I am absolutely convinced that basilica schemes, Latin cross schemes, are totally inadequate for the liturgy proposed by the Church.

As opposed to that single direction of precouncil plans where everything converged in a privileged point, in the presbytery containing the altar, one of the things demanded clearly by the liturgical reform is to separate in order to clarify. Above the altar, there used to be a tabernacle for the Eucharist reserve, where the sacrifice was celebrated; behind it, there used to be an altarpiece containing sculptures for the faithful to worship, everything was focused on a single point. The reform asks architects to separate: first, the area for celebrating the sacrifice from the area for the Eucharist reserve - I will leave this topic here though I believe that it is fascinating - and it asks us for a reflection on how these spaces should be qualified. It also asks us to differentiate clearly, within the area for celebrating the sacrifice, from 
the place for the Word proclamation (pulpit) to the place for presiding (see) and to the place for the real execution of the sacrifice, which is the altar. That is, that single direction has exploded; it has turned into a multidirectional thing, something requiring many non-simultaneous focal points, something very complex in which collective and personal things have to be included. The collective dimension - let us remember the definition of the subject made by the «Sacrosanctum Concilium», I would like to talk about it in more depth later- the place where God's people gathers in order to celebrate joyfully the mysteries of salvation. A temple is a reality with a unitary or collective dimension; it is the place where God's people gathers and, moreover, with a fascinating adjective, to celebrate joyfully. When the architect thinks that the temple is place where God's people gathers, that collective and community dimension has to be present. Moreover, the idea of a joyful celebration also requires, in my opinion, an approach which separates it from murky zones. But I insist in the idea that the former symmetry has been replaced with eurhythmy in the new structures; the single direction needs to be transformed into something multidirectional; the convergence on a specific point must explode in some sort of polycentrism.

That contemplative and static disposition has to be transformed into active participation; i.e., one of the basic conditions of the whole reform is determined by the will of actuosa participatio, the will of active participation. Therefore, I insist that Latin cross plans or basilica schemes are radically inappropriate: they are not designed for that. I find the previous example by Walter Zahner very beautiful, talking about the transformation of Saint Anthony's temple - I guess that it was in some Austrian city, I cannot quite remember-in which the same space is transformed according to the new necessities. I find that idea of communion fascinating and it talks perfectly well about that collective community space for gathering. Undoubtedly and in spite all, the architects must constantly put forward new schemes which improve particular aspects and which qualify better certain things which had not been well solved. That is one of my concerns, for instance, about the topic of the tabernacle position, which is often debated. I guess that no good solutions have been proposed.

\section{Constructed works}

I would like to share with you some of the proposals that I have made, although none of them is exemplary. However, their main advantage lies in their own reality: they have been built, they were possible and many ideals and intentions have been left behind. I will be critical to them, both with regard to what has to do with me and with regard to what has not. Maybe this will help us to reflect a little upon these new spaces.

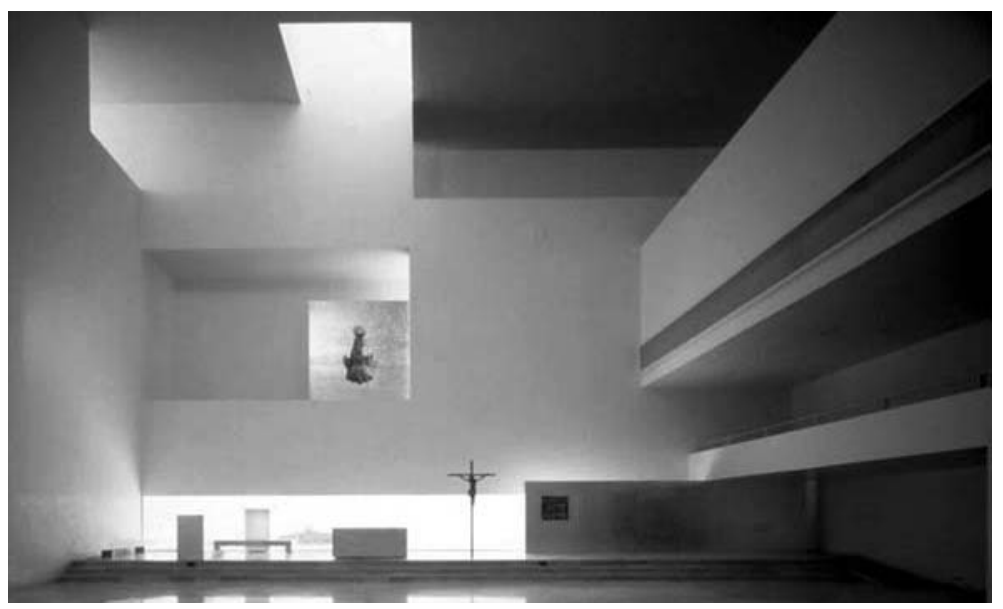

Capilla de la Residencia de las Hermanitas de los Ancianos Desamparados, Alcázar de San Juan (Ciudad Real), 1996.

sacrificio del ámbito de la reserva eucarística, tema que dejo aquí porque creo fascinante, y nos pide una reflexión sobre cómo se deben cualificar también esos espacios. Nos pide también que, dentro de ese ámbito de la celebración del sacrificio, se distinga claramente entre el lugar para la proclamación de la palabra —ambón-, el lugar de la presidencia - sede - y el lugar de la auténtica ejecución del sacrificio, que es el altar. Es decir, aquélla monodireccionalidad ha estallado, se ha convertido en algo pluridireccional, algo que exige muchos puntos de atención no simultáneos, algo muy complejo en lo que tiene que implicarse de alguna manera lo colectivo y lo personal. La dimensión colectiva —no olvidemos la definición que hace también la «Sacrosanctum Concilium» del tema, luego me gustaría comentarlo un poco más- el lugar donde el pueblo de Dios se reúne para celebrar gozosamente los misterios de la Salvación. El templo es una realidad que tiene una dimensión unitaria o colectiva; es el lugar donde el Pueblo de Dios se reúne y además — con un calificativo fascinante-, para celebrar «gozosamente». Cuando el arquitecto se plantea que el templo es el lugar donde se reúne el Pueblo de Dios, esa dimensión colectiva, comunitaria, tiene que estar presente. Pero además, la idea de «celebración gozosa», en mi opinión, exige también un tratamiento que lo separará de los ambientes tenebrosos. Pero insisto en la idea de que en las nuevas estructuras, la simetría anterior ha cedido ante la euritmia; la monodireccionalidad tiene que transformarse en una pluridireccionalidad; la convergencia en un determinado punto tiene que explotar en una suerte de policentrismo.

Aquella disposición contemplativa y estática tiene que transformarse en una participación activa; es decir, una de las condiciones básicas de toda la reforma viene determinada por esa voluntad de «actuosa participatio», voluntad de participación activa. Por lo tanto, insisto en que las 
plantas de cruz latina o los esquemas basilicales los encuentro radicalmente inapropiados: no están diseñados para esto. Encuentro bellísimo el ejemplo que nos ha planteado antes Walter Zahner de la transformación de ese templo de San Antonio - me parece que era en una ciudad austríaca, no recuerdo exactamente- en el que un mismo ámbito se transforma según las nuevas necesidades. Esa idea de la comunión pienso que es fascinante y habla perfectamente de ese espacio colectivo comunitario de encuentro. No cabe duda de que, a pesar de todo, nosotros, como arquitectos, tenemos que estar constantemente proponiéndonos nuevos esquemas que mejoren ciertos aspectos, y que vayan cualificando mejor algunas cosas que no estaban bien resueltas. Esa es una de mis preocupaciones, por ejemplo, con el tema de la posición del sagrario, que es siempre muy discutida y en la que, efectivamente, creo que no se ha llegado a buenas soluciones.

\section{OBRAS CONSTRUIDAS}

Me gustaría compartir con ustedes algunas de las propuestas que he hecho yo, aunque ninguna de ellas sea ejemplar. Tienen la ventaja de su propia realidad: han sido construidas, han sido posibles y en el camino se han dejado muchos ideales y muchas intenciones. Seré crítico con ellas en lo que me corresponde a mí y en lo que no me corresponde, pero puede que nos sirva a todos nosotros para reflexionar un poco sobre estos nuevos espacios.

\section{Alcázar de San Juan}

El primer ejemplo es una capilla, pero por su tamaño podría ser una iglesia. Pertenece a un enorme asilo de ancianos en Alcázar de San Juan, un pueblo de La Mancha. Un enorme asilo de ancianos, insisto, de unas monjas. Este edificio, con dos grandes alas, necesitaba incorporar también una capilla. La capilla se plantea - y esto creo que es una cosa necesaria - abierta al pueblo, de tal manera que se puede decir que es una iglesia: no es una parroquia, pero es una iglesia abierta al pueblo, y tiene que tener también entrada directa desde el exterior.

Primera cosa que creo que es interesante: la presencia del templo en la ciudad. Siempre ha sido el templo un punto de referencia, y pienso que esto es algo positivo a lo que no debemos renunciar. No creo en los templos camuflados más que en casos de necesidad imperiosa; pero no estamos en un momento de persecución - o por lo menos, no directa- $\mathrm{y}$ creo que en este momento es necesaria la afirmación de la presencia del templo en el tejido urbano.

El templo es complejo. Las Hermanitas de los Ancianos Desamparados tienen sus cosas bien claras, y ellas, de forma rotunda, decidieron que no iban a hacer una capilla del Santísimo aparte. No se hace y punto. De tal manera que hubo que llegar a esa especie de compromiso de conseguir que, de alguna manera, la capilla del Santísimo fuese sugerida por este espacio debajo del coro que es lateral, que a su vez venía determinado por la capilla de las monjas que estaba encima.
Alcázar de San Juan

The first example is a chapel which could be a church, due to its size. It belongs to a huge elderly people's home in Alcázar de San Juan, which is a town in La Mancha. I insist: a huge elderly people's home run by some nuns. The two-wing building required the addition of a chapel. The chapel was planned as something open to the people - I think that is necessary-, so that you can say that it is a church: it is not a parish, but it is a church open to the people, and it also needed to have direct entrance from the outside.

The first relevant thing here is the presence of the temple in the town. The temple has always been a reference point and I believe that is something positive which should not be rejected. I do not believe in camouflaged temples, unless it is strictly necessary; but we are not going through times of prosecution —or, at least, not directly - and I guess that it is necessary to reaffirm the presence of the temple in the urban tissue.

The temple is a complex one. It was clear to the Hermanitas de los Ancianos Desamparados that they did not want to make a separate chapel for the Holy Sacrament. They just did not want it. So a compromise had to be reached, in the sense that the chapel for the Holy Sacrament had to be suggested by that space under the lateral choir, which was in turn determined by the nuns' chapel above it. Another pre-requirement was that the Virgin of the Defenceless which had presided over the chapel for 150 years should remain there, and precisely at the same spot. I believe that this does not go in line with the liturgical reform, but we did it and I guess it is interesting.

The topic of the light has also been discussed. We looked for a non-domestic approach to light, a sort of set design approach which was determined by all those skylights...

\section{Collado-Villalba}

The next project is a church for a parish centre. This was somewhat more complex. It was in Villalba of Madrid, not Villalba of Lugo, a town located on the ridge near Madrid, in a rich area with plenty of granite, same as here. Given that the temple was in a rich area... let them open their wallets and pay for it!

We did a first project that did not go ahead. It was a granite prism with a planned entrance in swastika and a space as little directional as possible, taking into account that it is a square space. In order to avoid said directionality, we planned that the real directionality was the vertical one, and the basic argument was a huge skylight built out of a series of prisms with copper outside and golden inside, so that the space was basically vertical. The chapel of the Holy Sacrament was also clearly separate from the temple. The former had a dimmed light, as opposed to the strong light of the central space. 


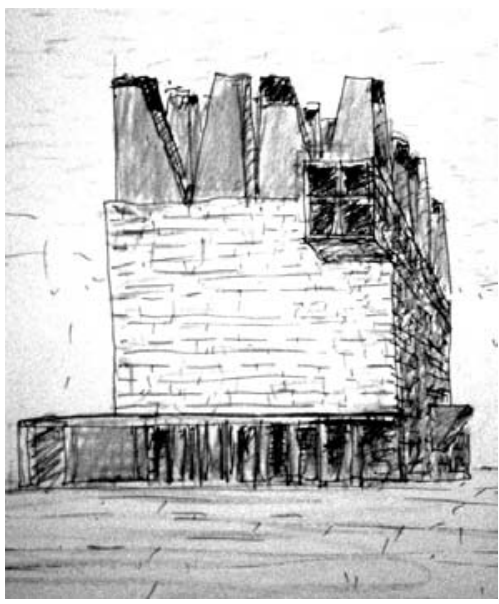

Well, this project was radically criticised. We were asked to bring down the height of the building, both the physical and the psychological height: they thought it was monumental. I would also like to talk a little about the concept of the monumental in religious architecture. In Spain, where temples have always been a reference, I think that saying that a temple could be too monumental is frankly ridiculous. Anyhow, it was demanded, so the following compromise was reached: a project which does not renounce what we considered as indispensable - the presence of the temple in town-but turns the façade into an altarpiece one (the temple was dedicated to the Holy Trinity). Moreover, this temple is just opposite the railway station, a very important meeting point. Everybody passes by, you know. Therefore, we thought that it was of essence to have a talking façade, shouting: here I am, here we are, and this is the church.

The whole height was concentrated in the façade and, anyhow, we organised a fully transparent cover where the light was dimmed by these huge beams of extraordinary edge which allowed the solution for the double function required. They asked us for an interior space which was low, horizontal and democratic; nevertheless, we thought it should be somewhat grand. The beams edge somehow allowed for it. The façade is not made of stone anymore; it should be made of concrete. So we draft that sort of altarpiece façade opposite the railway station containing three elements on a projection suggesting a porch; and clearly recalling the Father, the Son and the Holy Ghost. The remaining twelve straight elements have identical areas and stand for the twelve gifts of the Holy Ghost exploding in every direction.

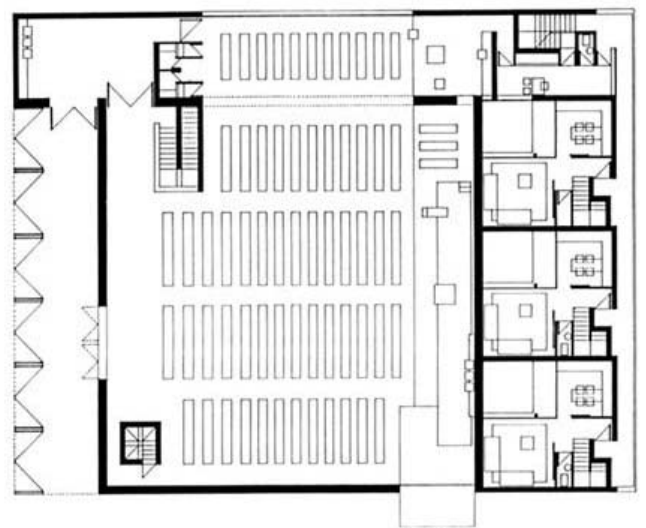

Iglesia parroquial de la Santísima Trinidad, Collado Villalba (Madrid), 1996/99. Primera propuesta.

Otra condición innegociable era que la Virgen de los Desamparados que había estado presidiendo la capilla durante ciento cincuenta años siguiera presidiéndola, y también exactamente en ese punto. Esto no está de acuerdo, yo creo, con la reforma litúrgica, pero bueno, lo hicimos, y creo que es interesante.

Se ha hablado también del tema de la luz. Aquí buscamos un tratamiento no doméstico de la luz, un tratamiento si se quiere escenográfico, que viene determinado por todos estos lucernarios...

\section{Collado-Villalba}

El siguiente proyecto es una iglesia para un centro parroquial. Esto era más complejo. Se trataba de Villalba de Madrid, no Villalba de Lugo, un pueblo que está en la sierra de Madrid, en una zona rica donde hay muchísimo granito, como aquí. Dado que el templo estaba en una zona rica... ipues que se aflojen la polaina y que paguen!

Hicimos un primer proyecto que lo no salió adelante. Era un prisma de granito, donde planteamos una entrada en esvástica y un espacio lo menos direccional posible dentro de que, en definitiva, es un espacio cuadrado. Para evitar también esa direccionalidad, planteábamos que la auténtica direccionalidad era la vertical, y el argumento básico era un enorme lucernario construido con una serie de prismas del cobre al exterior y dorados al interior, de manera que el espacio fuera un espacio básicamente vertical. También se separaba claramente la capilla del Santísimo del templo. La capilla del Santísimo tenía una luz mucho más tamizada, frente a la luz potente del espacio central.

Bien. Este proyecto fue criticado radicalmente. Se nos pidió que redujéramos la altura del edificio, la altura física y la psicológica: se pensaba que era monumental. Me encantaría hablar también un poco del concepto 


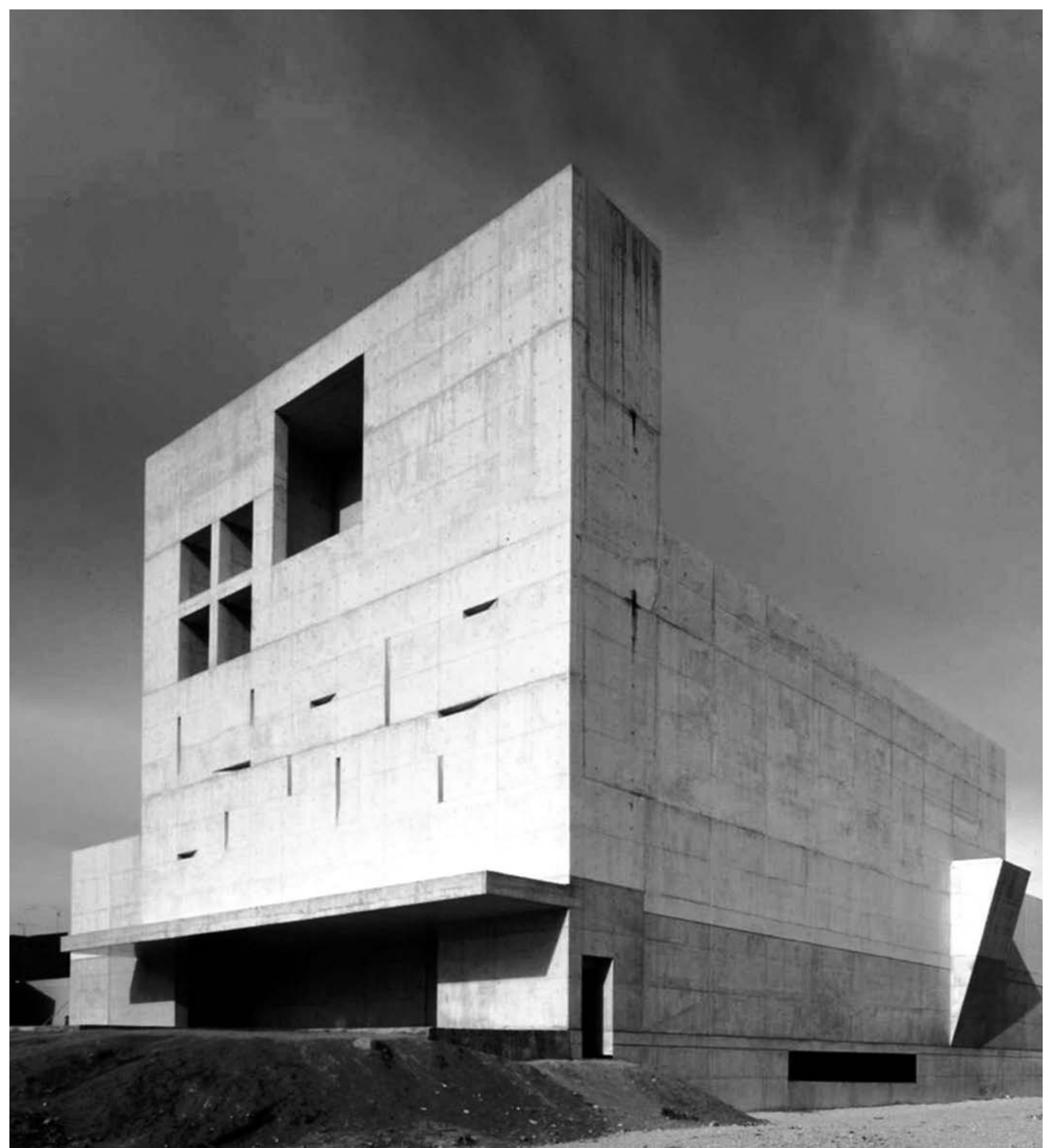

Iglesia parroquial de la Santísima Trinidad, Collado Villalba (Madrid), 1996/99. 


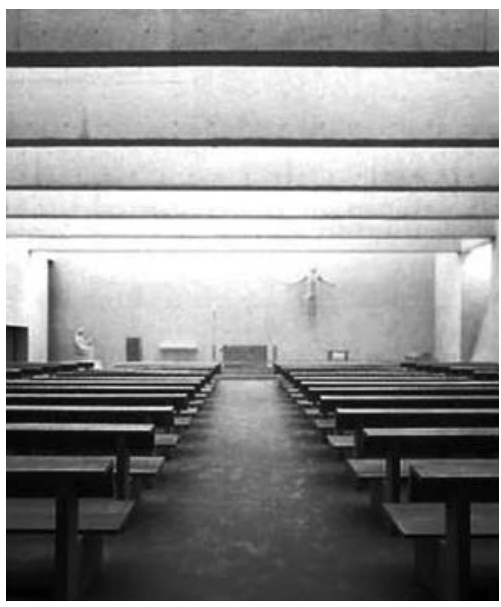

The final solution turns the temple into an altarpiece façade. There is no interior altarpiece. I would also like to refer to the altarpiece topic. I do not believe in them or understand their efficacy nowadays. Well, this could also give rise to a debate. I will just show you a church with an altarpiece that I recently made. I do not believe in it, but it was requested.

The lateral elevation and the sections are determined by the huge edge of these beams. It was requested that light should be as intense as possible in the area of the people gathering to make a joyful celebration. However, this has to be achieved providing shade from Madrid's horrible sunshine thanks to the beams edge. The sunshine could have made the area unfit for gathering. I believe that the wonderful Jesus Christ made by Javier Martinez — who is a great sculptor who had already collaborated with us-is a resurrected Christ, but one who is warm and talkative.

The light at the chapel of the Holy Sacrament is radically different, it is a gradient light. I would like to make a short reflection on this. As opposed to the community space, the chapel of the Holy Sacrament is a place for private prayer; therefore, it makes sense to have a dimmed light there, which could even be dramatic or set design lighting, if you wish. I have tried to approach in a clear way different types of lighting for each of my churches, as far as this was possible.

\section{Rivas Vaciamadrid}

I would like to present now one of my greatest failures, although I am really fond of this church. However, it must be admitted that it is unfinished. The works started 6 years ago, there is not

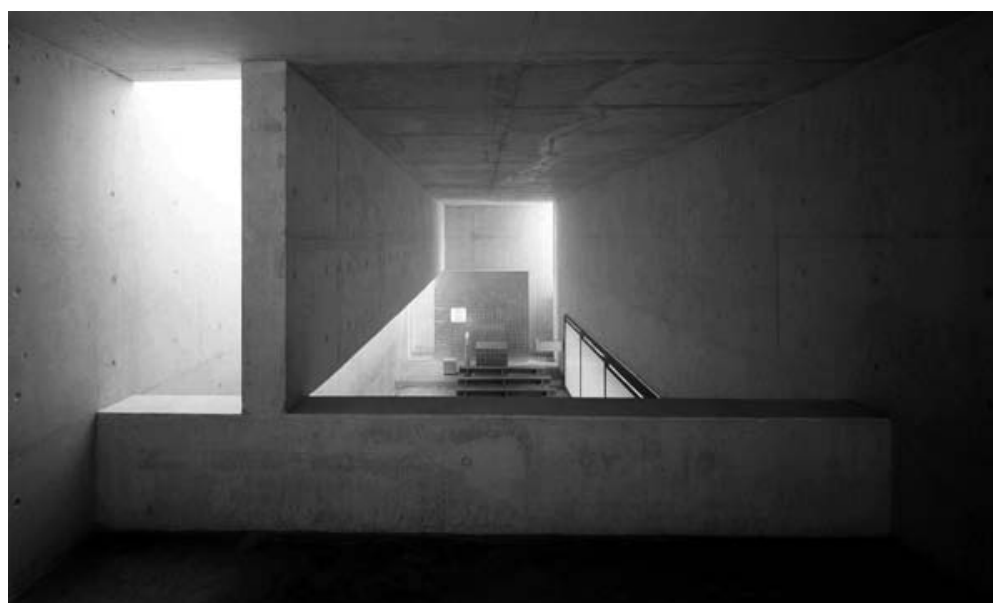

Iglesia parroquial de la Santísima Trinidad, Collado Villalba (Madrid), 1996/99.

de lo monumental en la arquitectura religiosa. En España, donde los templos han sido siempre una referencia, hablar de que un templo pueda llegar a ser excesivamente monumental me resulta francamente ridículo. Pero en fin, el hecho es que se pidió y el compromiso al que se llegó fue éste que les muestro: un proyecto que, sin renunciar a lo que considerábamos imprescindible - que era la presencia del templo en el pueblo-, transforma la fachada en una fachada retablo (el templo está dedicado a la Santísima Trinidad). Además, este templo está justo enfrente de la estación de tren, que es un punto importantísimo de encuentro. Todo el mundo pasa por ahí, vaya. Con lo cual, nos parecía extraordinariamente importante que la fachada fuera parlante, que dijera: aquí estoy, aquí estamos, esta es la iglesia.

Concentramos toda la altura en la fachada, y de todas formas, organizamos una cubierta totalmente transparente en donde la luz quedaba tamizada por estas enormes vigas, de un canto extraordinario, que permitían resolver la doble función que nos pedían. Nos pedían que el espacio interior fuera bajito, horizontal y democrático; y sin embargo, nosotros consideramos que tenía que tener una cierta presencia. El propio canto de las vigas permitía, de alguna manera, esto. La fachada deja de ser de piedra: se nos pide que sea en hormigón. Planteamos esa especie de fachada-retablo hacia la estación de tren, en la que, sobre un voladizo que permite una sugerencia de porche, aparecen sus tres elementos, en clara referencia al Padre, al Hijo y al Espíritu Santo. Los otros doce elementos rectos tienen áreas idénticas: son los doce dones del Espíritu Santo explotando en las cuatro direcciones.

En la resolución final, el templo se convierte en una fachada retablo. No hay retablo interior. Me gustaría hablar también del tema del retablo. No creo en ellos, no veo su eficacia hoy en día. Pero bueno, también puede 

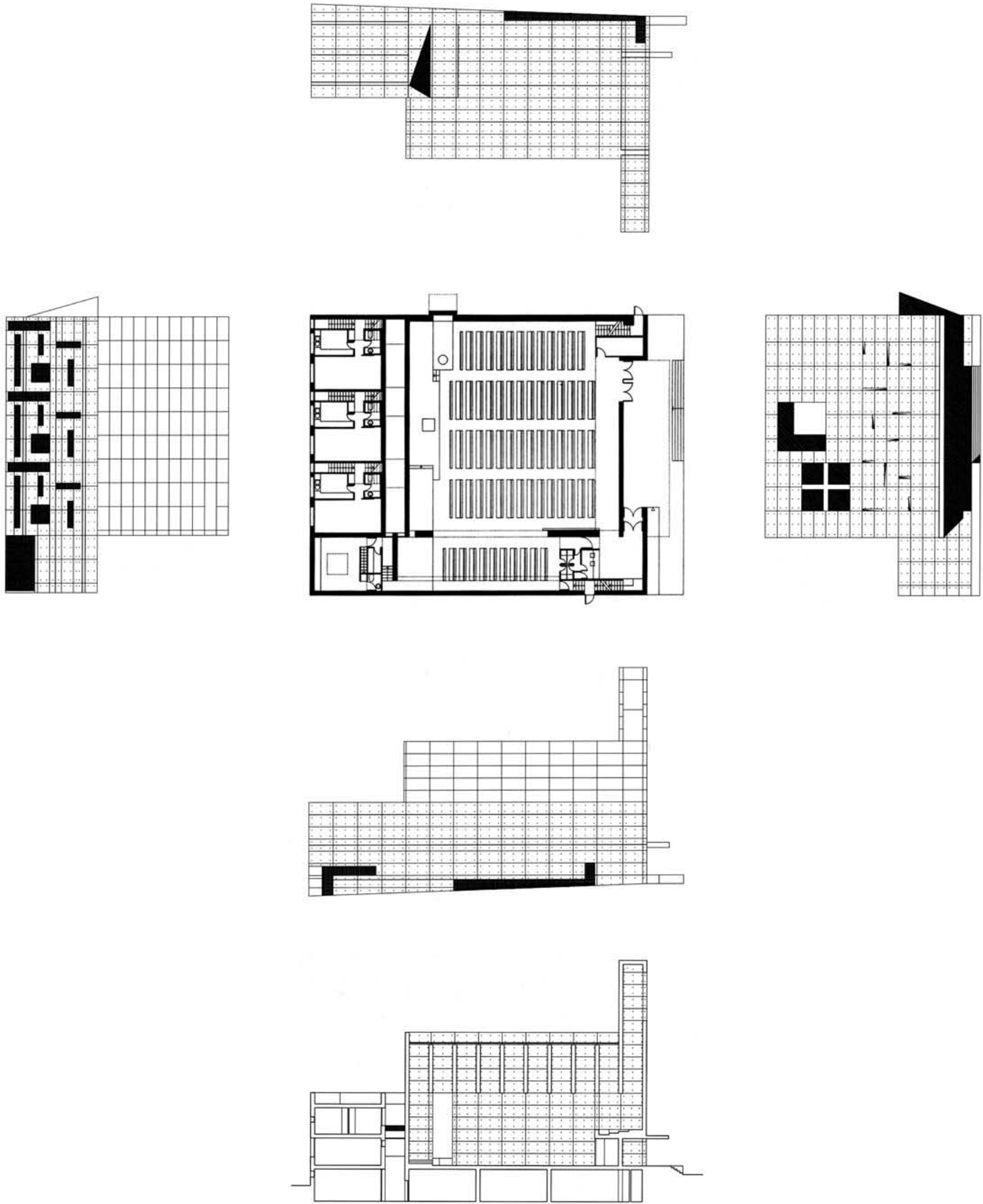

Iglesia parroquial de la Santísima Trinidad, Collado Villalba (Madrid), 1996/99. 
enough budget to complete it, we are trying to beg from everyone. Curiously enough, when it is completed, I guess that it will be one of those places where contemporary artists have left their traces: the chapel of the Holy Sacrament has been totally painted by José Manuel Ciria, one of the most important. The spectacular virgin made by Javier Viver, is going to be a gem. The Christ has been gifted by José Luis Sánchez, one of the big names of religious sculpting from the $60 \mathrm{~s}, 70 \mathrm{~s}$ and 80 s, still alive; thank God, though not active. However, he has presented us with a Christ. That is, there is no money, there is nothing, the work is being accomplished with a few cents; still, there is a will to see it through. Well, we have been working for 8 years now.

Nevertheless, I intend to discuss my failure, since this was one of the temples in which I had a greater interest and I believe that it put forward an interesting solution at a very difficult place. This was the first draft that was never carried out: it remained a draft, therefore it was never accomplished. I would just like to mention one idea: the place where this church was to be built was a spare lot, as it often happens in most places where dwellings are to be built. There was a spare long and narrow plot which was useless, so it was gifted to the Church in order to build a temple.

Obviously, it was accepted: you need to accept it all. And our question was: how to build such a centralised thing in such a narrow plot? Then I remembered one of my advantages, the advantage of being old and having met so many masters. Sometimes you recall one of those gems from the back of your mind, as Oiza said: If you have a long thing, make it even longer. So, instead of trying to fit a square, centralised element into that long area, let us increase the difficulty. We had to reduce 5 metres here and there, and that is what we did. So we planned a longitudinal body with access from a veranda looking onto the garden, with the parish centre on one side, access to the priests' houses above, the sacristy, the chapel of the Holy Sacrament and an even longer and narrower temple.

All of us who belong to the Academia know that our speech is often contaminated by historical remarks and references, even if we do not notice. I have sometimes explained - being absolutely true - that the plan of Sant'Andrea al Quirinale, by Bernini, is present in our plan. Bernini did the hardest trick of an ellipse where the bigger axis became the subordinate one, while the smaller axis became the important one: entrance axis and altar axis. That is, what we did was to transform the whole scheme where the smaller axis becomes the hierarchical one, where the altar is at the centre and the see by its side. Then the bigger axis is the democratic one, i. e., where the people gather, slightly sloping. But when you go down, ser también un tema a discutir. Inmediatamente después les presentaré una iglesia con retablo que acabo de hacer. No creo en él, pero así me lo han pedido.

El alzado lateral y las secciones vienen determinados por el enorme canto de estas vigas. Se nos pide que en el ámbito del pueblo que se reúne para celebrar gozosamente, la luz sea lo más intensa posible. Esto se hace, pero protegiéndose del sol terrible de Madrid — que podría haber inhabilitado el espacio - con el propio canto de las vigas. Creo que el maravilloso Cristo que hizo Javier Martínez - un escultor espléndido al que ya le hemos pedido muchas cosas - es un Cristo resucitado, pero acogedor y que habla.

La capilla de Santísimo tiene una luz radicalmente distinta. Me gustaría hacer una pequeña reflexión sobre esto. Es una luz rasante. Si a diferencia del espacio comunitario, la capilla del Santísimo es un lugar para la oración personal, entonces creo que ahí sí que es más lógico que la luz sea mucho más tamizada, a veces incluso hasta dramática o escenográfica, si se quiere. En casi todas mis iglesias, he intentado que, en la medida de lo posible, el diferente tratamiento de la luz en estos casos se viera de una forma clara.

\section{Rivas Vaciamadrid}

Presento ahora uno de mis grandes fracasos, y eso que es una iglesia a la que le tengo un cariño extraordinario. Pero bueno, aceptémoslo, está sin terminar. Empezamos la obra hace seis años, no se encuentra dinero para terminarla, estamos «sableando» a todo el mundo. Curiosamente, cuando se termine, creo que será un ejemplo de lugar donde los artistas contemporáneos han dejado su impronta: la capilla del Santísimo ha sido pintada totalmente por José Manuel Ciria, uno de los grandes. La Virgen, espectacular, que ha hecho Javier Viver, va a ser una joya. El Cristo lo ha regalado José Luis Sánchez, uno de los grandes nombres de la escultura religiosa de los años sesenta, setenta y ochenta, hoy todavía vivo gracias a Dios, aunque no trabaja. Pero nos ha regalado un Cristo. Es decir, que no hay dinero, no hay nada, la obra se está haciendo con dos duros; pero hay voluntad de que se haga. En fin, llevamos ocho años.

Pero quiero hablar de mi fracaso porque este era uno de los templos en los que yo había depositado un mayor interés y que creo que planteaba una solución interesante dentro de un sitio muy difícil. El primer proyecto, que no se llevó a cabo, era éste: se quedó en anteproyecto, y por lo tanto, no se hizo. Me interesa señalar sólo una cosa: el lugar en el que se tenía que construir esta iglesia era una parcela sobrante, como suele pasar en casi todos los sitios en donde se construyen viviendas. Allí sobraba un sitio muy estrecho y muy largo, que no servía para nada, y que, por tanto, se regaló a la Iglesia para hacer un templo.

Entonces se aceptó, como es lógico: hay que aceptar todo. Y nos planteamos esto: ¿cómo se hace en un solar tan estrecho algo centralizado? Recordé una de las ventajas: la ventaja de ser mayor y de haber tenido 

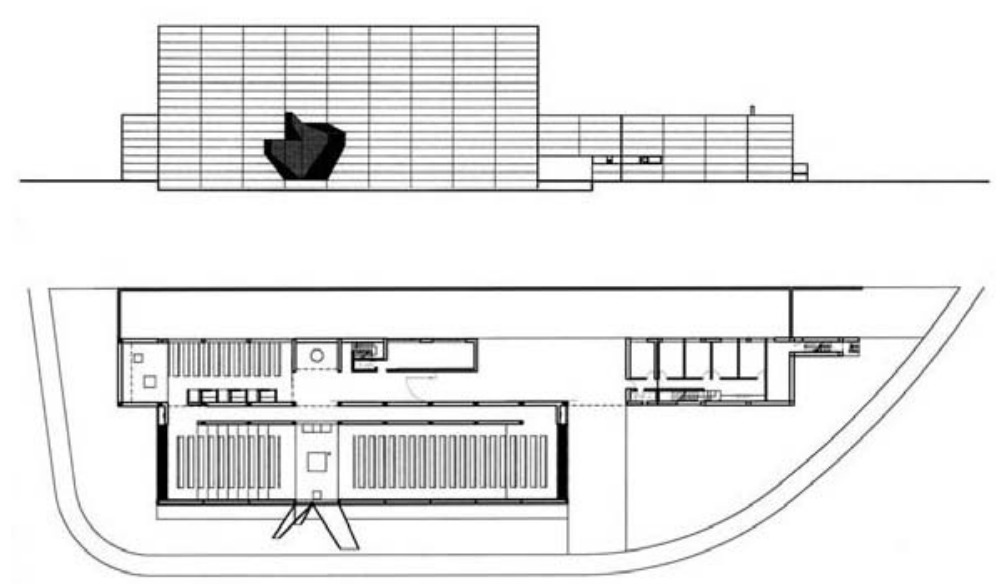

Iglesia parroquial de Santa Mónica, Rivas Vaciamadrid (Madrid), 1999/09. Primera propuesta.

maestros y de haberlos conocido. Es que, de vez en cuando, uno recuerda esas perlas que le quedan en la cabeza. Nos decía Oíza: «Cuando tengáis una cosa larga, estirarla más». Y eso fue lo que hicimos. En lugar de intentar incluir dentro de este espacio largo un elemento cuadrado, centralizado, incrementamos todavía más la dificultad. Había que retranquearse cinco metros de aquí y de allá. Entonces planteamos un cuerpo longitudinal que tenía el acceso desde un porche porticado que daba paso al jardín, el centro parroquial - a un lado-, el acceso a las viviendas de los sacerdotes por encima, la sacristía, la capilla del Santísimo y el templo, largo y todavía más largo y estrecho.

Todos los que nos movemos en el mundo de la Universidad sabemos cómo se contamina nuestro discurso con connotaciones históricas, referencias, hasta sin darnos cuenta. Alguna vez he explicado - y es verdad, es la pura realidad - que en esta planta está muy presente la planta de Sant'Andrea al Quirinale, de Bernini. En donde Bernini hace el «más difícil todavía» de la elipse en la cual el eje mayor se convierte en el subordinado y el eje menor se convierte en el eje importante: eje de entrada y eje del altar. Esto, qué duda cabe, está presente también aquí. Es decir, que lo que nosotros hacemos es transformar todo este esquema, en donde el eje menor se convierte en el eje jerárquico, donde el altar se pone en el centro y a su lado, la sede; y el eje mayor es el eje democrático - digamos-, donde está el pueblo ligeramente en descenso. Pero para bajar es necesario ir hacia un lado o ir hacia el otro. Creo que fue un esfuerzo importante, y que nos parecía muy interesante el cambio de ese eje jerárquico que venía determinado por una luz escenográfica y por un lucernario que, curiosamente, se convirtió luego en el argumento del proyecto definitivo, como verán después, mientras que el eje democrático venía determinado por una luz democrática y continúa. El templo era

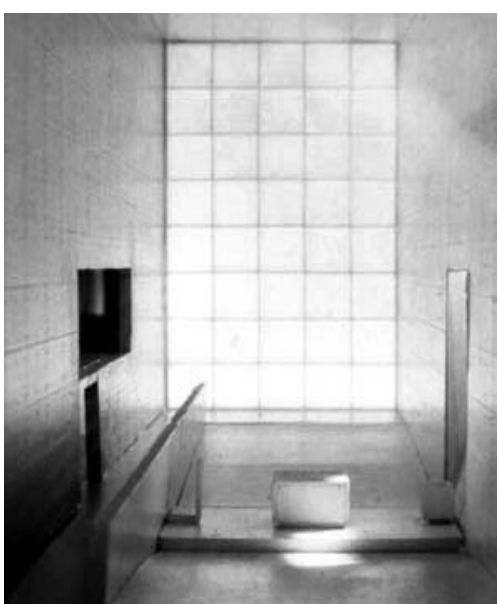

you need to proceed in one or another direction. I guess that it was a considerable effort, and we thought that the change of that hierarchical axis was very interesting, since it was determined by this set design lighting. There was also a skylight which later on became the key argument in the final project, while the democratic axis was determined by a democratic and continuous light. The temple was narrow and incredibly tall, whereas the parish centre and the priests'dwellings were long and short. Well, I think it is time to show some models explaining - somewhat roughly - how this smaller axis became the hierarchical one, while the other was the democratic one. We also planned the iconographic programme in such a way that, as you walk in, you can see only the two figures in the hierarchical axis: an angel on the side almost taking off towards the virgin, floating on the other side.

I believe that this proposal would have been hugely interesting and that it put forward a typologically suggestive plan; however, it was blown away. That is, we were clearly told, and it was demanded of us, to build a directional temple. You will understand how upset I was after all I have said here. Well, clearly directional means everyone facing forwards: directional plus altarpiece. That is what had to be done. We were also required to occupy as much space in the plot as possible.

This is the church that has been built or, rather, that is being built, since it is not completed. Given that it was required that we should build as much as possible within the plot, we reached $5 \mathrm{~m}$ on every side. That was the maximum. The priests'dwellings are at the top of the building, while the parish centre is at the bottom. Only a small fold is allowed, a small 


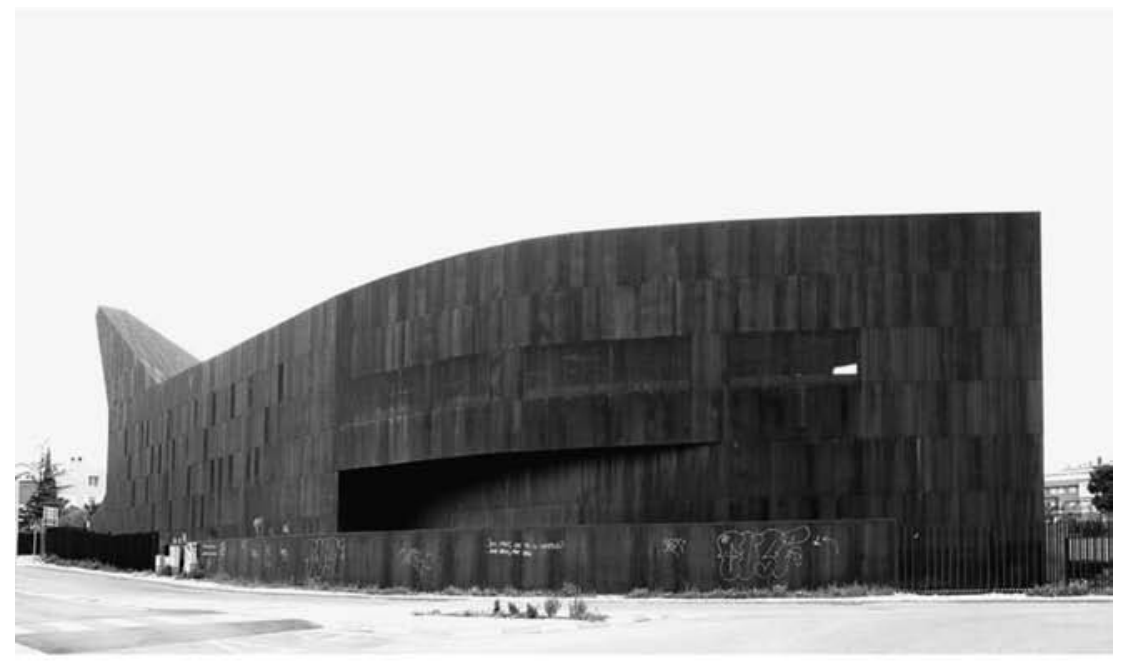

Iglesia parroquial de Santa Mónica, Rivas Vaciamadrid (Madrid), 2001/09.
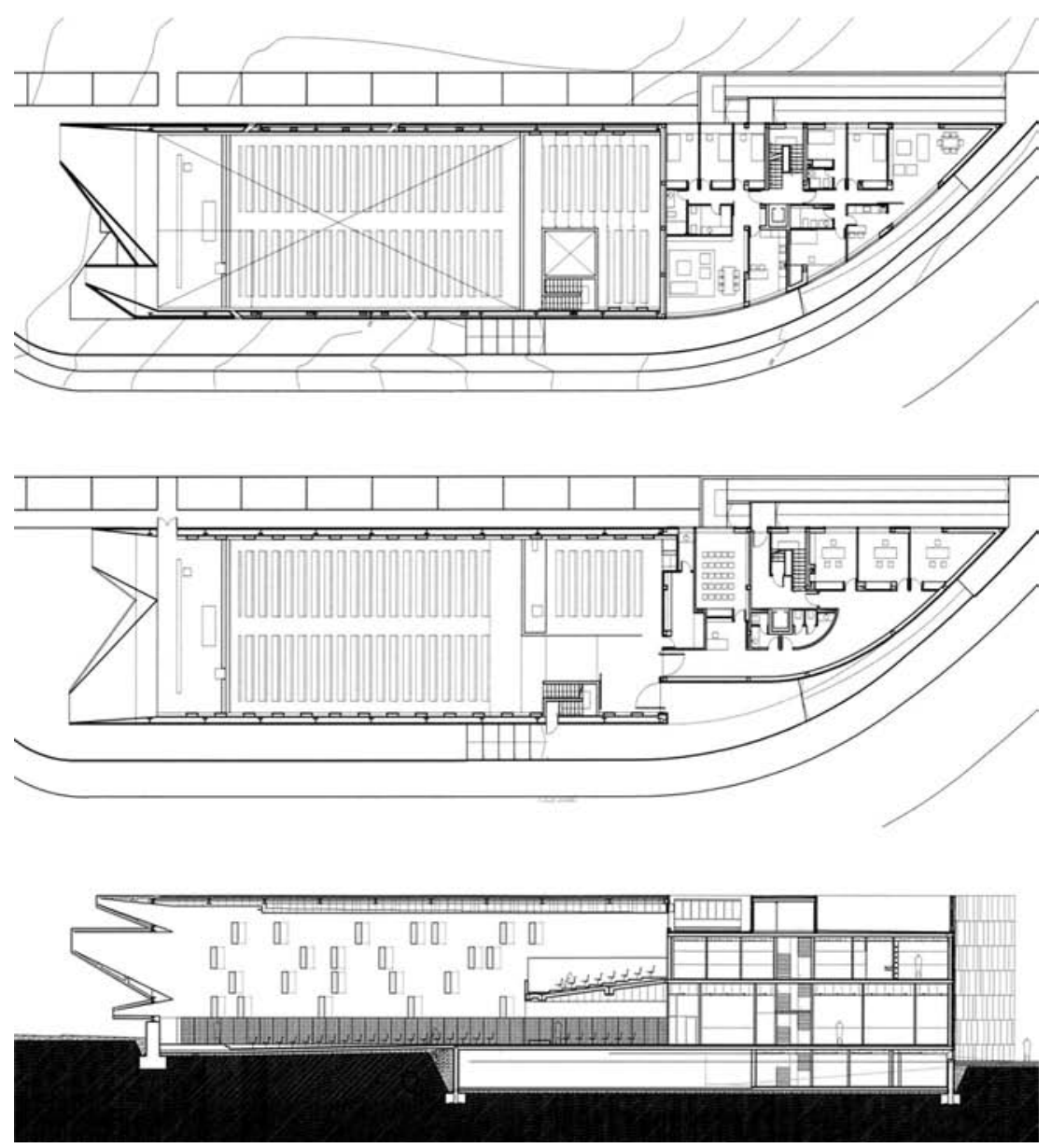


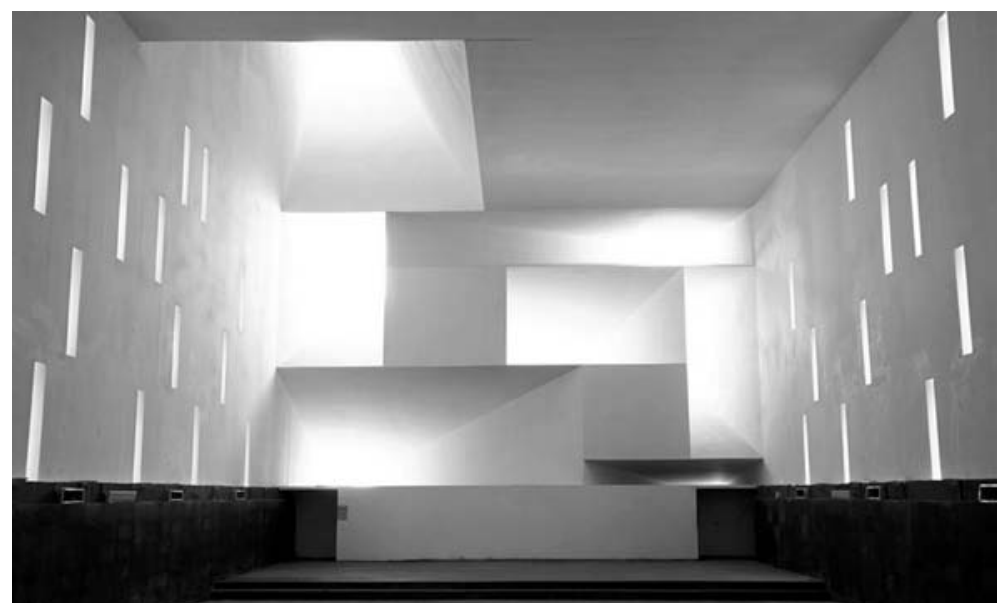

Iglesia parroquial de Santa Mónica, Rivas Vaciamadrid (Madrid), 2001/09.

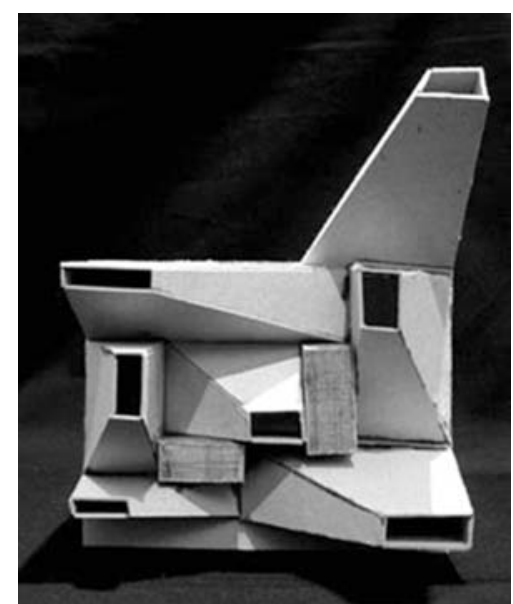

estrecho y altísimo, frente al elemento largo y bajo del centro parroquial y de las viviendas de los sacerdotes. Bien, creo que es interesante ver algunas maquetas que, de una forma un poco tosca, hablan de cómo este eje menor se convertía en el eje -insisto- jerárquico, frente al otro democrático. También planteamos el programa iconográfico, de tal manera que al entrar, todo el mundo podía ver en el eje jerárquico sólo las dos figuras que había: a un lado, un ángel casi en despegue libre hacia la Virgen, que flotaba en el otro lado.

Creo que era una propuesta que hubiera sido sumamente interesante, y que planteaba una planta tipológicamente sugestiva; y fue dinamitado. Es decir, se nos dijo claramente, se nos exigió, que el templo debía ser direccional. Después de todo lo que he dicho aquí, ustedes comprenderán mi desolación. Pero bueno, claramente direccional; es decir, todo el mundo mirando para delante: direccional y con retablo. Esto es lo que hubo que hacer. Y se nos exigió también que se ocupara el máximo posible de la parcela.

Ésta es la iglesia que se ha construido, o mejor dicho, que se está construyendo, porque sigue sin terminarse. Dado que se nos exigía agotar la edificabilidad, llegamos a los cinco metros en todos los lados: quiero decir, el máximo del máximo. Los pies del edificio los ocupan en la parte superior las viviendas de los sacerdotes y en la parte inferior el centro parroquial. Solamente se permite un pequeño pliegue - una pequeña pérdida de espacio - para sugerir la entrada al templo, que se plantea en términos claramente clásicos, vaya, si se quiere direccionales. Hay un presbiterio, hay una nave, todo el mundo mira hacia la nave, la capilla del Santísimo está aquí y hay un coro y hay un retablo: un retablo que es un retablo de luz. No había presupuesto y lo hemos hecho de la manera más barata posible. Todo está realizado en acero cortén porque se consiguió una persona que waste of space in order to suggest the entrance to the temple which is planned in clearly classical -i.e., directional-terms. There is a presbytery, a nave, everybody looking at the nave, the chapel of the Holy Sacrament goes here and there is an altarpiece: a light altarpiece. Since there was no budget, we have done it the cheapest way possible. Everything is made of COR-TEN steel, because we contacted a person who could help with that material. If we had obtained aluminium, the church would have been made of aluminium.

Since this continuous building explodes at the end with these skylights playing with the party walls, the only thing emerging is the parish centre with its own windows: all the rest are in disguise with panel elements. We worked in order to develop the head, i.e., the light altarpiece with comprising a series of skylights. This was the final solution reached after a long series of adventures.

The first graffiti has already appeared on the building. This was done before the fence was put up. The exploding skylights will later be seen from the inside. The whole thing is a really cheap metallic structure with an outer cladding of COR-TEN steel scales and an inner one made of plasterboard, that is, the cheapest of things. I may say that this church square metre is cheaper than the square metre of pavement from Prado Museum..

This is the colour of COR-TEN steel, as it is, and this is the entrance, that is, the only fold. A text and a light cross are missing here. The interior has not been completed either, nor the altarpiece. The side lights are purely white lamps, while the lights at the back will be determined by some golden backdrops to be planned. They also 


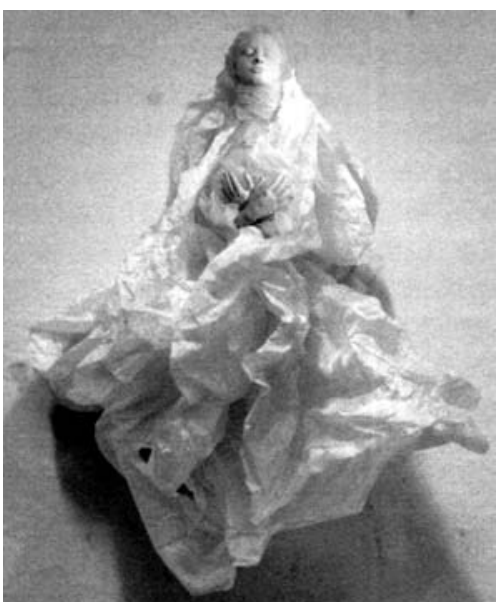

Javier Viver Gómez, Santa María Virgen. Boceto.

demanded that these two blind elements should be at the front, and we did so; they are two blind elements where the virgin and Saint Monica will be placed. Now I will present the iconographic project that we had put forward.

I would not like my words to be perceived as a criticism of any person; in any case, they are criticising a given situation.

The building is completely black. The lower part is all granite. Grids cover all of the air-conditioning pipes, the loudspeakers, etc. All of the areas prone to be spoilt by the people leaning on them are made of black slate, while the rest is white.

This is our project which is currently under construction. There are several —almost random - gilded pain d'or backdrops, so that colour qualifies light; it provides it with that special hue. This is the situation of the crucified Christ which is a wonderful Christ gifted by José Luis Sánchez. The virgin made by Javier Viver is obviously a clear Berninian example. Only two hands appear out of the turmoil of clothes, and they remind us of Saint Theresa's ecstasy but, instead of faint, they look withdrawn... and such a marvellous face. It is spectacular. I believe that this is an extraordinary work of art which deserves your attention. Well, I was in that scenario when I got the order of stopping everything because a certain someone was going to do... this! [Showing the altarpiece with a huge Saint Damian's Christ at the front.]

I insist that everything I am saying should not be perceived as a criticism of anyone, but as another hurdle that architects must overcome in order to see a work through.

That means that the skylights coming this way. As you all know, there were only two opaque elements ayudó con el acero cortén. Si hubiéramos conseguido aluminio, pues la iglesia hubiera sido aluminio.

Y como este edificio continuo explota al final, con estos lucernarios que están haciendo un guiño hacia las medianeras, lo único que aparece es el centro parroquial, que tiene sus propias ventanas: todas las demás están camufladas con elementos de chapa. Se trabajó en el desarrollo de esa cabeza, que iba a ser el retablo de luz compuesto por una serie de lucernarios. Finalmente, después de muchas aventuras, se llegó a esta solución.

El edificio construido ya tiene incluso las primeras pintadas. Esto se hizo antes de poner la verja que ya hay delante. Los lucernarios que explotan los veremos luego desde el interior. Todo es una estructura metálica extraordinariamente barata, con un recubrimiento exterior de escamas de acero cortén y un interior de Pladur, es decir lo más barato. Puedo decir que el metro cuadrado de esta iglesia es más barato que el metro cuadrado de pavimento del Museo del Prado...

Este es el color del acero cortén, tal como está, y esta es la entrada, es decir el único pliegue. Aquí falta un texto y una cruz de luz. El interior no está terminado todavía; tampoco está hecho el retablo. Las luces laterales son lágrimas puras, blancas, mientras que las luces del fondo estarán determinadas por unos paños dorados que vamos a plantear. También se nos exigió que estos dos elementos ciegos estuvieran en el frontal y lo hemos hecho; dos elementos ciegos donde se colocarán la Virgen y Santa Mónica. Ahora les presentó el proyecto iconográfico que nosotros habíamos planteado.

Me gustaría que nada de lo que estoy diciendo se vea como una crítica a ninguna persona; en todo caso, a alguna situación.

El edificio es totalmente negro. En la parte baja todo es granito. Las rejillas tapan todos los conductos de aire acondicionado, los altavoces, etc. Todo esto, toda la parte que es susceptible de ser manchada por la gente que se apoya, es pizarra negra, mientras que todo lo demás es blanco.

Este es nuestro proyecto, lo que se está haciendo ahora, en el cual aparecen varios paños — casi aleatorios - dorados con pan de oro, de tal manera que el color cualifica la luz, le da ese tono un poco especial. Y esta es la situación del Cristo crucificado, un Cristo espléndido que ha regalado José Luis Sánchez; la Virgen que ha hecho Javier Viver, evidentemente un claro ejemplo berniniano. Entre el magma de ropajes - que recuerdan al éxtasis de Santa Teresa- solamente aparecen dos manos que, en este caso, en vez de desmayadas están como recogidas... y esa cara maravillosa. Espectacular. Creo que es una obra absolutamente maravillosa y que ustedes deben ver sin duda ninguna. Pues bien, estaba en esa situación cuando recibí la orden de que se paralizara todo, porque cierta persona iba a hacer... jesto! [Enseña el retablo con un gran Cristo de San Damián colocado delante.]

Me interesa - insisto - que todo lo que digo no se lea nunca como una crítica a nadie, sino como una más de las muchas dificultades que tenemos los arquitectos para sacar adelante las obras. 
Esto significa que los lucernarios que vienen por aquí - como saben, solamente quedaban dos elementos opacos, donde iban a ir la Virgen y Santa Mónica: es real todo, como la vida misma-, pues curiosamente esos dos elementos que eran los únicos donde no aparecía luz, porque eran de metal, se transformaban en unas vidrieras iluminadas artificialmente, por supuesto; se introducía este Cristo - no sé cómo llamarlo, bizantinoinmenso; se iba a hacer este altar, hecho de patas torneadas de madera, y este ambón a juego...

Esta es la vida del arquitecto, ante la que caben dos posibilidades: el suicidio o la lucha. Si pongo estas imágenes, insisto, es solamente para animarles a todos ustedes a no tirar la toalla jamás. Evidentemente, cuando yo recibí todo esto, pues cogí la lógica depresión que sólo se puede curar con un doble vodka-tonic. ¡No es posible, a estas alturas del partido! Bien. Pues es posible, se puede.

$\mathrm{Y}$ tengo que decir que esto otro es lo que se está haciendo en este momento: se está colocando la Virgen de Javier Viver. Está ya ahí, con todos los andamios, colocándose. Hemos conseguido que una conocida modelo y actriz - cuyo nombre no debo decir ahora porque a lo mejor ya se dirá - nos pague el pan de oro y el altar — los dos altares - y los dos ambones. Hemos conseguido que José Manuel Ciria - el pintor excepcional- pinte gratis: y ya ha pintado la capilla del Santísimo con un ciclo sobre la creación absolutamente espectacular, que habrá que ir también a verlo. Se ha conseguido colocar el Cristo de metal. ¡Hay esperanza, a pesar de todo!

\section{Ponferrada}

Y quiero terminar mi intervención con un ejemplo muy positivo, porque a lo mejor en lo anterior había alguna carga negativa que venía mal. Este es un ejemplo absolutamente admirable: el ejemplo de un Obispo que quiere hacer una obra importante; el ejemplo de un ecónomo, Ángel Vallejo - hay que decir los nombres de las personas de la diócesis de Astorga- que dice que posiblemente sea la única iglesia que hagamos en esta diócesis durante nuestra vida — creo que es una diócesis en recesión-: ¡tenemos que hacerla!

Tengo que decir que así como en todos los demás casos he hablado de las dificultades que un arquitecto encuentra, aquí no ha habido más que facilidades. No sólo facilidades, más aún, tensiones para que mejorásemos y lo hiciésemos mejor. En este caso, el templo parroquial de Ponferrada ocupa un lugar enorme, una inmensa parcela rodeada de edificios altísimos, de edificios de viviendas de dieciocho y veintitantas plantas, inmensos. La opción, en este caso, ha sido lógicamente el contraste. Como el templo no puede afirmarse mediante la altura, se afirma mediante la horizontalidad. Esto parece bastante claro y tampoco tiene ningún secreto: no hay que ser Einstein para llegar a ello.

El templo se deja en una esquina del solar, justo al lado del acceso principal — este es un sitio importante-, y las viviendas de los sacerdotes left for the virgin and Saint Monica: everything is as real as life itself. Well, curiously enough, those two elements made of metal, which were the only two without light, turned into stained-glass windows with artificial lighting, of course; that Byzantine, immense Christ was introduced. I do not know how to describe it; they were planning to put this altar made of shaped wooden legs, together with this pulpit...

That is the architect's life, and you have two choices: suicide or fighting. If I am showing you these pictures is just with the purpose of enticing you not to give up. Obviously, when I saw all of this, I felt naturally depressed and resorted to a double gin and tonic with vodka as the only cure. It was not possible at that stage! Well, it certainly was.

I must say that this is what they are doing at the moment: placing Javier Viver's virgin. They are already fitting it with the whole scaffolding. We have managed to get a well-known model and actress to pay for the pain d'or and altar, both altars and both pulpits - but I cannot name her now, maybe she will be named later-. We have managed to have the extraordinary painter José Manuel Ciria paint pro bono; he has already painted the Holy Sacrament chapel with a totally spectacular cycle about the creation, you have to see it too. We have managed to fit the metal Christ; there is hope, after all.

\section{Ponferrada}

I would like to finish my presentation with a very positive example, because maybe the aforementioned contained some negative load which was unfit. This is an absolutely admirable example: that of a bishop who wants to make an important work; the example of a church administrator, Angel Vallejo - the names of the people from the Astorga diocese need to be quoted - who says that this may well be the only church built at this diocese in our whole lives. I think that this diocese is undergoing a recession: we have to build it!

I must say that, just like I have spoken in every instance about the difficulties faced by architects, here we have found only advantages. Not just advantages, but tensions so that we improved and did a better job. In this case, the Ponferrada parish church occupies a huge plot surrounded by very tall buildings, by 18 or 20 storey blocks of flats, huge ones. In this case, we have clearly opted for the contrast. Since the temple cannot be reaffirmed through height, it does through horizontality. This seems quite clear and holds no secret: you need to be no Einstein to figure it out.

The temple is at one side of the plot, right next to the main access which is an important place, while the priests' dwellings and the parish centre occupy the more acute part of the triangle integrating the plot, as if to say. 


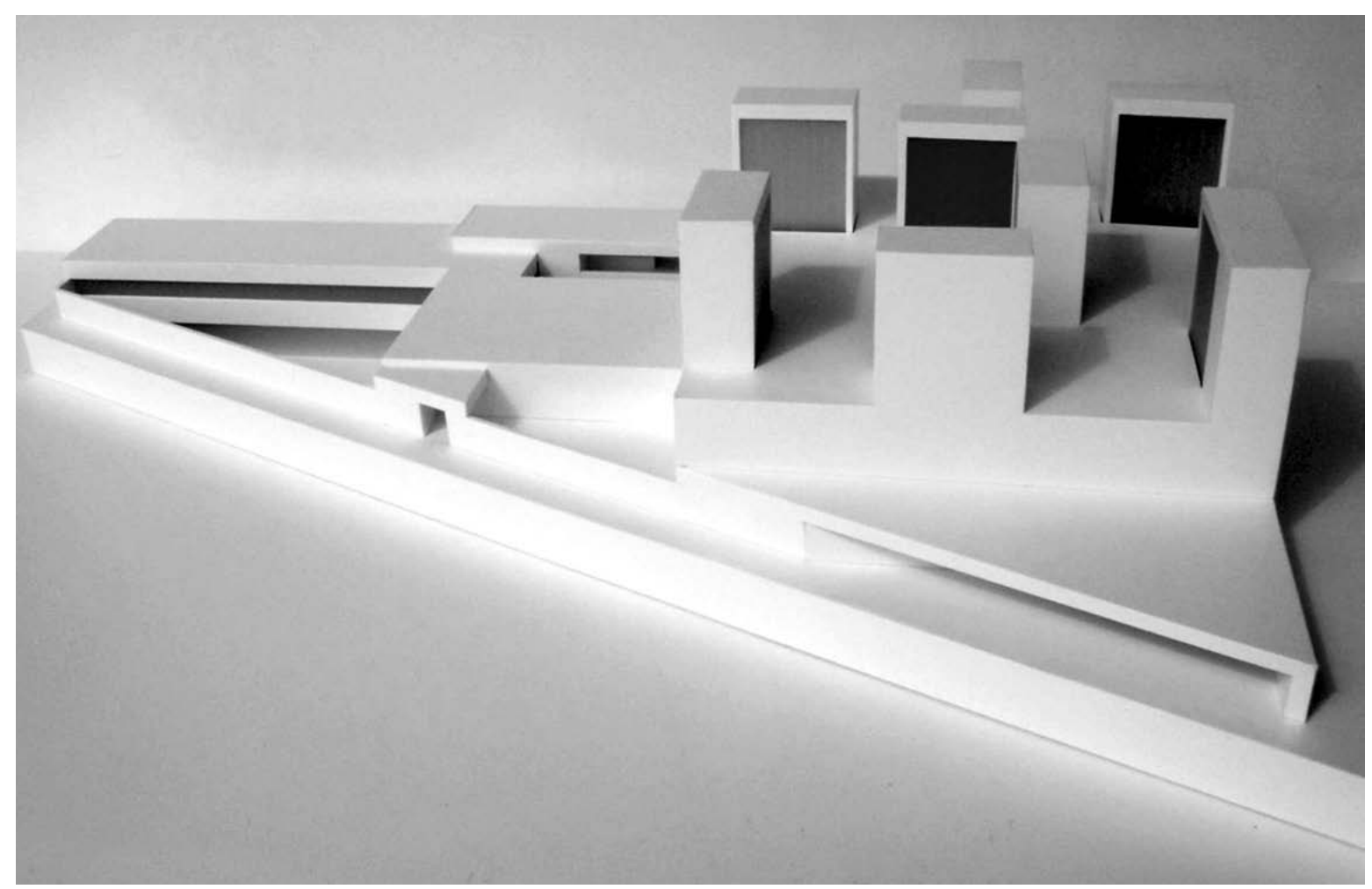

Iglesia parroquial de Nuestra Señora de Los Rosales, Ponferrada (León), 2004. Proyecto.

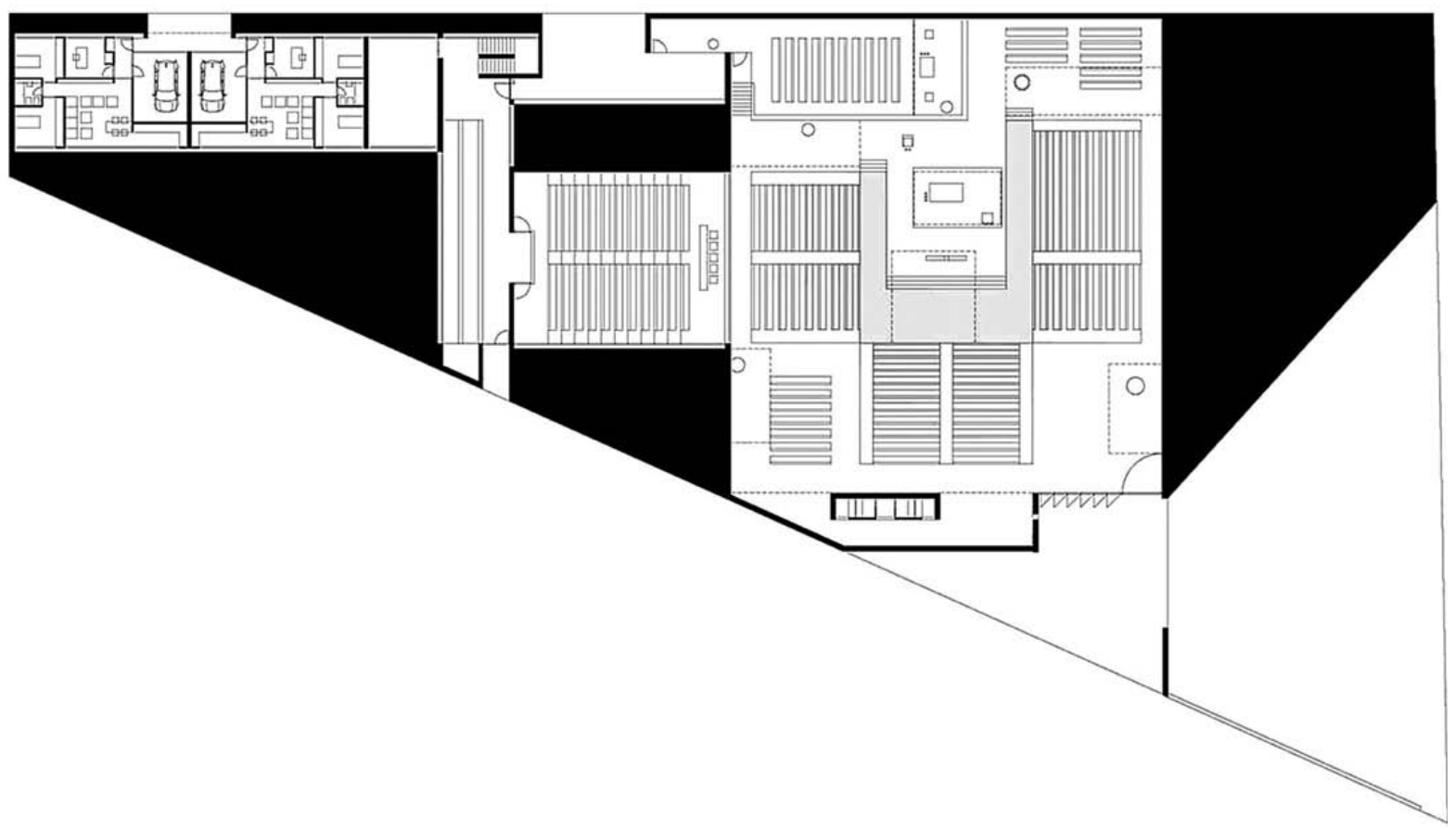



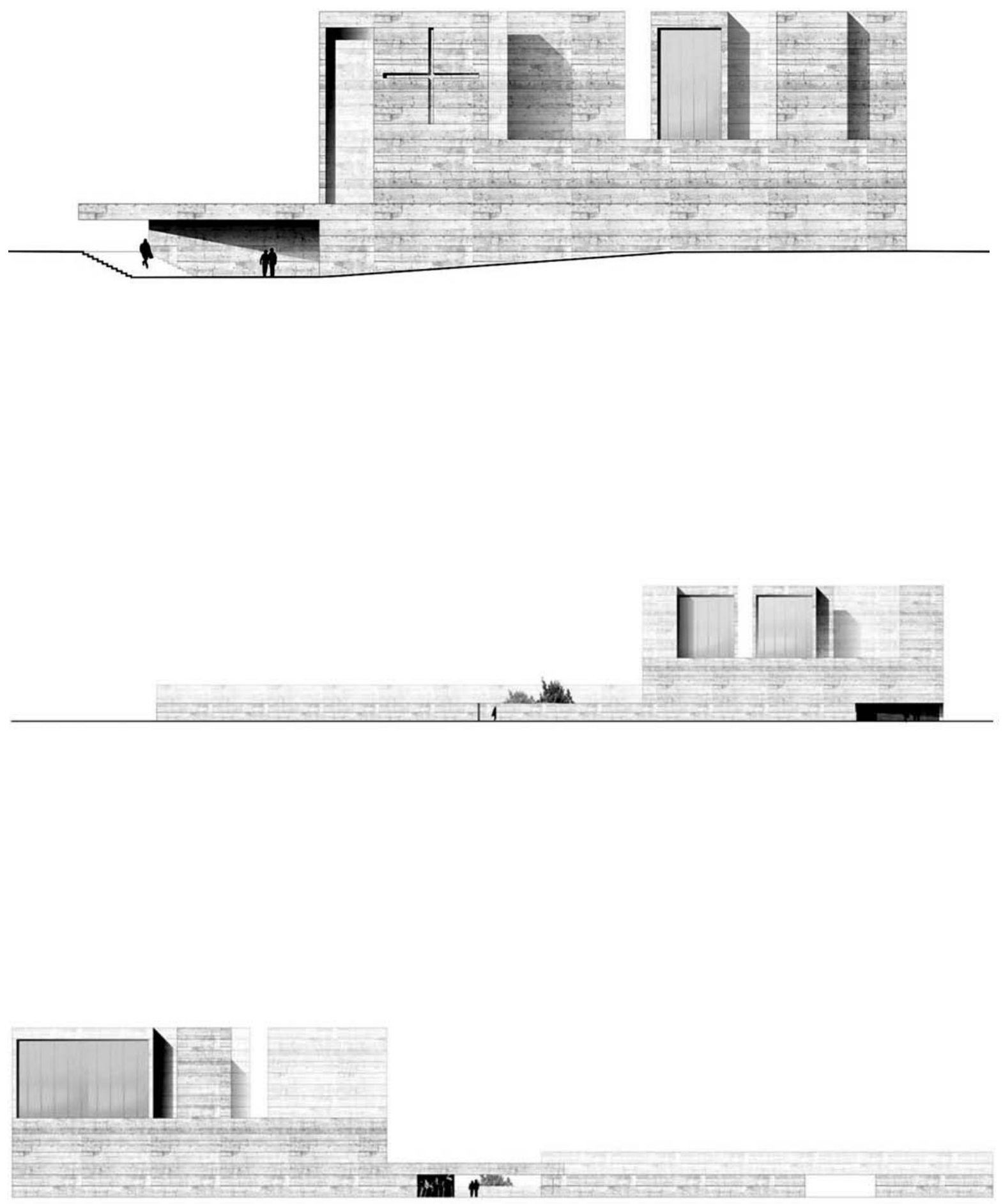

Iglesia parroquial de Nuestra Señora de Los Rosales, Ponferrada (León), 2004. Proyecto. 
The temple is conceived as really low, with access through a porch on one side. It is crowned by a series of skylights eventually generating light, if so they wish... that is, if we were pedantic -like good professors - we might say that it stands for the deconstruction of the stained-glass window; since we are not pedantic, we will not say it. Each skylight is built with a single colour. However, I guess that the plan is the most interesting thing because, for the first time, we have provided it with a centralised shape which really works.

The plan has the advantage of having each skylight for qualifying each of the areas. Obviously, the presbytery is slightly highlighted in order to determine the actual difference between the common priesthood of the faithful and the priest's ministerial priesthood. But this is done very subtly, so that the stairs separating them are just two. The people surround the presbytery; this area descends slightly in height and there is also a chance to enlarge the nave.

They are very optimistic at this diocese. They believe that Ponferrada needs some worship places. They are really optimistic as regards their capability to teach the catechism. They also requested that the centre conference hall could be opened for special ceremonies, thus increasing extraordinarily the church capacity. This is particularly interesting to me -I cannot tell more, since I have run out of time, but I think this was something I had in mind - I mean, that was 25 years ago, in that first project in Almeria which I could not show here since it was not built. I am referring to that concern about the chapel of the Holy Sacrament abandoning the secondary place it usually occupies and becoming also a protagonist. The fact of placing the chapel of the Holy Sacrament with direct access from the outside for weekly days, since it is located higher up, this allows the tabernacle to preside at all times, high above, because it is much higher than this level, so it never clashes, as if to say, with the altar, but still presides the space, even when the church is empty. I think that this could be an interesting solution. Well, time is out, so I must finish. I could tell you how each of those skylights will talk about the sacraments, in the best Gaudi tradition. One of them is above the baptistery, another one above the penitential chapel, another one above the presbytery, etc.; and each of them will carry their names, just to make it clear. I can also recall another gem that the masters used to say, a History professor in this instance, Chueca Goitia: the best way to identify a building is placing a sing on its facade. y el centro parroquial ocupan la parte — digamos_- más aguda del triángulo que forma la parcela.

El templo se concibe como algo francamente bajo, con un porche de acceso por uno de sus lados. El templo viene coronado por una serie de lucernarios que van a producir una luz, si se quiere... es decir, si fuéramos pedantes - como buenos profesores universitarios - diríamos que es la «deconstrucción de la vidriera»; pero como no somos pedantes no decimos que es eso. Cada lucernario se construye con un solo color. Pero lo que creo que es más interesante es la planta, a la que por primera vez hemos podido darle una forma centralizada, que realmente funciona.

Una planta, además, que cuenta con la suerte de que cada uno de los lucernarios cualifica uno de los ámbitos. Evidentemente, el presbiterio está ligeramente realzado para determinar, también, la diferencia real entre el sacerdocio común de los fieles y el sacerdocio ministerial del sacerdote. Pero muy sutilmente, de tal manera que los peldaños que los separan son solamente dos. El pueblo rodea el presbiterio; este ámbito baja ligeramente de cota y existe la posibilidad de que la nave se pueda ampliar.

Son muy optimistas en esta diócesis. Creen que Ponferrada necesita espacios de culto. Son realmente optimistas respecto a la capacidad catequética. Nos pidieron también que el salón de actos del centro pudiera abrirse para ceremonias especiales; así se aumentaba extraordinariamente la capacidad de la iglesia. Y algo que me resulta especialmente interesante - y no voy a comentar más, porque se me ha pasado el tiempo, pero yo creo que es algo que tenía en la cabeza: estoy hablando de hace veinticinco años, en el primer proyecto en Almería que no he expuesto aquí porque no se hizo - es esa preocupación por que la capilla del Santísimo, de alguna manera, abandonara el lugar subordinado en el que habitualmente se suele poner y fuese también protagonista; de tal manera que colocando la capilla del Santísimo con una entrada directa desde el exterior para los días de diario y estando más alta, nos permite que el sagrario presida siempre, muy por encima, porque está muy por encima de este nivel, de tal manera que no entra nunca en colisión, digamos, con el altar, pero sin embargo preside el espacio incluso cuando la iglesia está vacía. Creo que esto es una solución que puede ser interesante.

Bien, se me ha acabado el tiempo, así que termino. Les contaría cómo cada uno de estos lucernarios - en la mejor tradición gaudiniana- hablará de los sacramentos. Y cómo uno de ellos está encima del baptisterio, otro encima de la capilla penitencial, otro encima del presbiterio, etc.; y en todos, para que quede claro, se pondrá su nombre. Porque recuerdo también otra de las perlas que nos decían los maestros, en este caso un catedrático de Historia, Chueca Goitia: que la mejor manera de identificar un edificio es poner un letrero en el frontispicio.
Cf. Constitution on the Sacred Liturgy "Sacrosanctum Concilium" (1963), $n^{\circ} .123$.

Cf. Andrés Pardo Rodríguez, coord., «Enchiridion. Documentación litúrgica posconciliar", Regina, Barcelona, 1992.
Cf. Constitución sobre Sagrada Liturgia "Sacrosanctum Concilium» (1963), n. 123.

Cf. Andrés Pardo Rodríguez, coord., «Enchiridion. Documentación litúrgica posconciliar», Regina, Barcelona, 1992. 